\title{
TER VERDEDIGING VAN HET CHRISTENDOM
}

\author{
GRONDTREKKEN VAN KIERKEGAARDS ETHOS \\ VAN DE BEWAPENDE NEUTRALITEIT
}

\author{
TIMO SLOOTWEG
}

"Zalig is hij, die zich aan mij niet ergert." Matt. 11; 6

\section{\$1 Over de polemiek met het Christendom: nu en toen}

We leven in een tijd waarin het religieuze, het Christendom in het bijzonder in het defensief is. Het Christendom lijkt zich te moeten verdedigen tegenover de geest van Verlichting en Humanisme, alsook tegenover het soort van kritiek dat eerst helder verwoord werd door links-hegelianen en marxisten. Ik noem slechts enkele kritiekpunten. Religie (het goddelijke bevel) is strijdig met de vrijheid van de mens en is als zodanig inhumaan. $\mathrm{Zij}$ is een toestand van zelfopgelegde onmondigheid en als zodanig 'opium van het volk'. Religie houdt de mensen dom, en zij houdt daarom de vooruitgang tegen: 'Sapere aude' - Heb de moed zélf na te denken! Vooral waar het gaat om de verhouding tussen politiek en religie wordt de religie voortdurend ter verantwoording geroepen omdat zij een bedreiging vormt voor de soevereiniteit van de staat en de wetgever. Daarom: 'écraser l'infâme' (Voltaire); vermorzel die schandelijke kerk! De religie heeft zich te verantwoorden voor de rechtbank van de menselijke rede, de theoretische (de wetenschap) en praktische rede (de moraliteit), en sinds die redelijke standaard gehanteerd wordt dreigt de religie daaraan ten onder te gaan.

In zijn tijd heeft ook Kierkegaard (1813-1855) gemeend het op te moeten nemen voor het religieuze, meer in het bijzonder voor de Christelijke religie. Maar, en dat is cruciaal, hij heeft Christendom niet willen verdedigen tegenover de groeiende seculariteit, het humanisme en het atheïsme. Dit 'heidendom' heeft zelfs zijn sympathie en mededogen omdat het in zekere zin nog te naïef is en niet ver genoeg ontwikkeld om werkelijk vertwijfeld te kunnen zijn. Wanneer men zich inspant om een zo weinig geestrijke cultuur te richten, zoals dat toen gebeurde en sindsdien alsmaar opnieuw, dan staat dat (in zekere zin) gelijk aan het trappen tegen een lijk. 
Nee, de verdediging van Kierkegaard staat op een ander, hoger niveau. Zijn polemische apologie is erop gericht het Christendom te verdedigen, niet tegenover al diegenen die het open en eerlijk aanvallen, als wel tegenover diegenen die het willen verdedigen tegen die kritiek. Dat zijn onder anderen diegenen voor wie de moderne secularisatie, de totale scheiding van religie en politiek (van kerk en staat) veel te ver gaat, en die zij dan ook beschouwen als een vorm van rebellie tegen God. Ook gaat het om hen die de religie beschouwen als een geneesmiddel tegen de splijtzwam van het moderne rationele en geseculariseerde leven. Déze verdediging, die ook tegenwoordig weer in allerlei toonaarden weerklinkt, richt zich vooral tegen 'de malaise van de moderniteit'; tegen een gebrek aan saamhorigheid en burgerschap waardoor mensen zich nu steeds minder identificeren met hun politieke samenleving; tegen een cultuur van 'narcisme', 'sociaal atomisme', 'romantisch expressivisme', 'moreel subjectivisme' en 'relativisme'. Dat is een cultuur die (mede) verklaard wordt uit de teloorgang van het religieuze, waardoor allerlei levende, normatieve verbanden en 'zuilen' zijn weggevallen. ${ }^{1}$ Om dit culturele verval tegen te gaan hebben we nu dus weer meer religie nodig, zo luidt het. ${ }^{2}$ Alleen een heropleving van de Christelijke religie, een ervaring van de religieuze heiligheid van maatschappelijke instituties kan ons nog bewaren voor de vigerende, heilloze individualisering. Vandaar ook dat men zich zo inzet voor een verwijzing naar 'onze' Christelijke wortels in het ontwerpverdrag voor een Europese Grondwet. Zo heeft onlangs ook Paus Benedictus XVI de verschillende godsdiensten opgeroepen samen te werken om met elkaar de vigerende, goddeloze secularisatie te bestrijden.

Deze lijn van verdediging - het Christendom gepresenteerd als sociaal binden redmiddel tegen het vigerende consumentisme, materialisme, nihilisme,

${ }^{1}$ Zie bijvoorbeeld Charles Taylor, The Malaise of Modernity, Ontario, Canada, Stoddart Publishing Co. Ltd., Don Mills, 1991, alsmede zijn Varieties of Religion Today. William James Revisited, Cambridge Mass., Harvard UP, 2002. Taylor levert een door Hegel geïnspireerde kritiek op het traditionele liberale denken over het individu. Hij pleit tegen een vrijblijvend liberalisme, voor een hernieuwde, geestelijk-religieuze 'inkadering' van het geatomiseerde, 'onthechte' individu in allerlei sociale verbanden en 'moral frameworks'. Taylor wijst ook op de fundamenteel dialogische 'horizon' van het mens-zijn en benadrukt het geborgen-zijn in een bovenpersoonlijke, objectief-geestelijke bedding. Ook fundamentele levenskeuzes krijgen pas zin tegen de achtergrond van deze sociale betekenishorizonten. De 'gemeenschappelijke zijnswijze' van religie zou een belangrijk panacee zijn.

${ }^{2}$ Zie Ad Verbrugge, Tijd van Onbehagen. Filosofische essays over een cultuur op drift, Amsterdam, SUN, 2004). Volgens Verbrugge dreigt de Nederlandse cultuurgemeenschap ten onder te gaan aan een gebrek aan religie die het wezen van de cultuur vormt. Want in religie, en speciaal in de geopenbaarde religie (het Christendom), vindt een mens zijn bovenindividuele bestemming. Religie en godsdienst (Verbrugge denkt aan het belang van een Nationale Kerk) verheffen het individu tot een wezenlijke saamhorigheid; zij heiligen een deugdzaam en bezield gemeenschapsleven, in het huwelijk, in het volk en in de staat. 
antropocentrisme, egocentrisme en tegen de onttovering - is gebaseerd op uitgangspunten die volgens Kierkegaard - en hij beroept zich op de beginselen van de Reformatie - niet eigenlijk Christelijk zijn. En hetzelfde geldt voor een verdediging van zogenaamd Christelijke deugden, normen en waarden die de menselijke natuur - de mens als politiek wezen - zouden kunnen vervolmaken. Onder die condities, op grond van die verkeerde uitgangspunten mee te willen doen met het publieke debat - om aldus het Christendom te willen zalven en verantwoorden - is net zo verraderlijk als de kus waarmee Judas eens Christus aan zijn moordenaars uitleverde. Daarom is pas déze strijd - die tegen het 'geestelijk materialisme' van deze zelfverklaarde 'Christenen' - het werkelijk waard gestreden te worden. Want het is een ernstiger zonde te volharden in zijn vertwijfeling wanneer men daar eenmaal over in kennis gesteld is. En de 'kampioenen' van het Christendom kunnen geacht worden te 'weten' wat het Christendom is en wat het voor de existentie betekent. Ze 'weten' het heus, want het is aan hen openbaar gemaakt, maar zij verkiezen die boodschap in de wind te slaan.

Deze bijdrage beoogt niet een specialistische, uitputtende behandeling van álle inzichten die Kierkegaard met betrekking tot dit thema heeft ontwikkeld en die inderdaad overal in zijn oeuvre verspreid liggen. Het artikel biedt een beknopte schets van enkele belangrijke (formele) aspecten van de ingewikkelde, polemische kritiek op de verdediging van het Christendom zoals Kierkegaard die in de periode van zijn 'tweede schrijverschap', vanaf 1847, ontwikkeld heeft. Actueel belang daarvan is, dat wij ons tegenwoordig in een vergelijkbare situatie bevinden; hoezeer ook in andere opzichten de context waarin hij schreef verschilt van die van de onze. De uiteenzetting is in dit verband nadrukkelijk opbouwend bedoeld. Want net als voor Kierkegaard in zijn tijd, geldt ook voor de huidige polemiek dat men ervoor zou moeten waken, met een misplaatst beroep op religie en Christendom, de duivel uit te drijven met Beëlzebub. ${ }^{3}$

\footnotetext{
${ }^{3}$ Kierkegaard wordt ook wel bestempeld als de voorloper van de generatie van '68, waarvan nu wordt aangenomen dat al haar wilde experimenten in 'subjectivisme' mislukt zijn, en dat dit (in retrospectief) het gelijk bewijst van de traditionele 'objectieve benaderingswijzen' (bijvoorbeeld: het klassieke en scholastieke natuurrecht die vandaag de dag een nieuwe opleving lijken door te maken). Wij mogen het ons echter niet te gemakkelijk maken. Het kenmerkende individualisme van deze 'zwarte schapen' werd weliswaar door het existentialisme beïnvloed (al was het dan veeleer het atheïstische existentialisme van Sartre). Maar zoals hieronder beargumenteerd wordt, moet Kierkegaards denken, tegenover het bescha-vingsoffensief van de hedendaagse verdedigers van het zelfverklaarde 'traditionele' Christendom, juist worden opgevat als een pleidooi voor een meer oorspronkelijk geloofsleven. Het is in de eerste plaats om de gewelddadigheid van de pseudo-Christelijke metafysica aan te tonen, en niet omwille van een persoonlijke voorkeur voor enige vorm van protestantisme, dat ik hier verschillende keren zal verwijzen naar de Bijbel, vooral naar Paulus, naar Augustinus en (bovenal) naar Maarten Luther, met wie Kierkegaard veel gemeen heeft.
} 


\section{$\S 2$ De aard van de apologie bij Kierkegaard}

Allereerst moet worden vastgesteld dat het bij Kierkegaard niet gaat om de verdediging van het Christendom als leer of doctrine (Christus was geen professor en zijn leerlingen vormden geen geleerd genootschap). Daarmee onderscheidt die zich van de klassieke apologie. Deze bedoelt een algemene, religiefilosofische grondslag van de dogmatiek te formuleren. De scholastiek deed dit vooral door middel godsbewijzen die gepresenteerd werden alsof zij absoluut onweerlegbaar zouden zijn. Kierkegaard gaat het erom het Christendom tegen deze traditionele, onpersoonlijke apologetiek te verdedigen. Hij wil het Christendom uitleggen als fundamentele categorie van de existentie; als een oorspronkelijk existeren of zelfzijn. Het Christendom is een principium individuationis, het is geen doctrine en geen leer, en het kan noch op speculatieve noch op moraaltheologische wijze worden begrepen en uitgelegd.

Toch is dat precies wat men - Kierkegaard refereert vooral aan patriarch Mynster en bisschop Martensen - in reactie op de aanval vanwege de Verlichting meent te moeten doen. Men probeert het Christendom overeind te houden en te verdedigen, door te laten zien dat het lang niet zo irrationeel is en tegen het verstand in gaat om te geloven, maar dat juist in het immanente en natuurlijke bereik van de mensheid (zelfs bij andersdenkenden; bij de vijand zélf) allerlei 'aanknopingspunten' van een religieus verlangen te vinden zijn; een natuurlijk verlangen naar een algemeenheid waarin tenslotte de goddelijke bestemming van de mens gelegen zou zijn. Men wil het Christendom verdedigen tegenover de verlichtingskritiek door het aldus meer aannemelijk te maken. Men wil het aannemelijk maken door de paradox van het geloof te verwijderen en het transcendente met het immanente te verzoenen. Het centrale leerstuk voor dit 'eenheidsdenken' is dat wat (volgens hen) door de openbaring over de incarnatie bekend is geworden.

Voor de Christenheid is God mens geworden; in tegenstelling tot het Joodse geloof waarin God de Geheel Andere blijft, aan gene zijde van de werkelijkheid en het bewustzijn van de mens. Maar, zo zegt men, met deze voorstelling van de menswording Gods is eigenlijk een zuiver immanent-transcendente idealiteit bedoeld (die van de Godmens in ons allemaal), die als zodanig pas in de moderne tijd, in de rationele, speculatieve wetenschap op begrip gebracht is. Welbeschouwd is het niet het enkele subject dat aan het goddelijke participeert voor zover het persoonlijk van God weet te getuigen. Zó ernstig en 'subjectief' mogen wij de particulariteit van Jezus Christus niet opvatten, dat wij als enkeling zouden zijn opgeroepen met Hem (als enkeling) gelijktijdig te worden. Nee, het is daarentegen de algemene mens, de generatie, de gemeenschap, de 
staat, het universele, de mensheid als geheel, die de Godmens representeert. De 'slechte oneindigheid' van het Joodse geloof, en de bovennatuurlijke, Joodse resten in de primitieve voorstellingswijze van het Christelijk tijdperk zijn daarmee (in beginsel) opgeheven. Zo verdedigt men het Christendom tegen de aanvallen vanwege de Verlichting. Het bijgeloof geldt slechts de esthetische voorstellingswijze (de vorm) en de al te primitieve, 'onredelijke' opvatting daarvan. Inhoudelijk gezien echter, en in essentie, is het geloof juist helemaal in overeenstemming met de rede.

Tot zover eerst (in vogelvlucht) de hegeliaanse context waarin Kierkegaard leefde en werkte. Voorlopig volstaat dit om te begrijpen waarom Kierkegaard zich wenst te verdedigen, niet tegen de tegenstanders van het Christendom, maar tegen deze (Christelijk-pantheïstische) apologetiek. Zoals ik hieronder verder zal betogen wordt de mens door de idealistisch-apologetische doctrine van de verzoening een idool. De verdediging past de Openbaring aan aan de beperkingen, vooroordelen en vergissingen van de menselijke rede. Door deze 'accommodatie' wordt de ware God verraden, en van het Christelijk geloof als zodanig blijft aldus niets meer over.

Kierkegaards polemisch antwoord op dit verraad is echter niet opnieuw op algemene, systematisch-theologische wijze de doctrinaire grondslag van het Christendom te herhalen. Zijn vraag naar religiositeit is er een die niet in abstracte beschouwingen blijft steken, maar eerst en vooral vanuit de concrete existentie gesteld wordt. Het is die persoonlijke opdracht waarvan hij de psychologische en antropologische dialectiek wil uitleggen. Ik beperk mij hier allereerst tot een geserreerd memorandum van wat hij daarover heeft opgeschreven in De ziekte tot de dood (1849); het wordt met recht beschouwd als één van de belangrijkste theologische werken van de negentiende eeuw. ${ }^{4}$ Dat wij met dit werk beginnen is nodig voor een goed begrip van de daar en elders geëtaleerde verdediging van het Christendom. ${ }^{5}$

${ }^{4}$ Zie Emanuel Hirsch, Kierkegaard-Studien, I-II, I, Gütersloh, 1933; repr. Vaduz, Liechtenstein, Topos Verlag, 1978, p. 229. Ik verwijs bij mijn bespreking van Kierkegaard naar (indien beschikbaar) de Nederlandse vertaling van zijn werk, en naar de vierde uitgave van de SKS (Søren Kierkegaards Skrifter, Kopenhagen, Gads Forlag, 1994 -).

5 De ziekte tot de dood is één van Kierkegaards pseudonieme geschriften. Dat wil echter niet zeggen dat het een voor hemzelf geheel vreemde gedachtewereld weergeeft. Vanwege de hem ootmoedigende idealiteit van het werk heeft hij pas op het laatste moment besloten het uit te brengen onder naam van 'Anti-Climacus' (zo ging het trouwens ook met Het begrip angst van 1844, dat uiteindelijk onder naam van Vigilius Haufniensis werd uitgebracht; van Anti-Climacus' Oefening in het Christendom, van 1850 heeft Kierkegaard achteraf gezegd dat hij het beter onder zijn eigen naam had kunnen uitbrengen). Dat neemt echter niet weg dat het boek in verregaande mate de gedachten van 
Niet 'het goede', of 'de liefde in het algemeen' interesseert hem. Want het 'zuivere denken' hierover, gaat voorbij aan de existerende geest, de ethiek van de enkeling voor wie het goede en de liefde pas eigenlijk gestalte krijgt. 'Het goede' en 'de liefde' zijn niet direct mededeelbaar want zij hebben geen objectieve, maar 'slechts' een subjectieve en relatieve betekenis. Zonder eerst een zelf te worden - een enkeling tegenover God - kan ik er ook voor de ander niet werkelijk zijn. Ik weet dus pas hoe ik moet handelen als ik de moed heb om eerst open en eerlijk tegenover mijzelf te staan. De vraag die gesteld moet worden is dus niet: 'wat is het überhaupt en in het algemeen om Christen te zijn?'; maar: 'hoe word $i k$ een Christen?', en 'hoe word $i k$ mijzelf als Christen? Dat bereikt men (kortweg) niet door als individu te vervluchtigen in allerlei fantastische pseudoreligieuze abstracties - het blijft dan steeds bij de zuivere mogelijkheid (men droomt zich weg uit de existentie) - maar door eerst werkelijk mijzelf te zijn. Ik ben mijzelf slechts voor zover ik mij bewust tot mijzelf verhoud. Want in dit dynamische en dialectische 'zich tot zichzelf verhouden' is juist mijn geest en mijn vrijheid gelegen (SKS 11, 129). In relatie tot mijzelf, ben ik (meer bepaald) de opgave de tegenstellingen die ik ben - zowel eindigheid als oneindigheid; zowel noodzakelijkheid als mogelijkheid; zowel tijdelijkheid als eeuwigheid - tot een synthese te maken. Dit is een opgave voor het leven, een voortdurend streven, want het 'zich verhouden', de synthese is nooit definitief voltooid maar altijd weer voorwerp van een nieuwe verhouding. Bovendien zijn wij voor het ware evenwicht dat wij te zijn hebben, aangewezen op de standaard van de hogere macht - 'God' - die ons in het leven gesteld heeft. Wij kunnen niet, zonder in een nieuwe vorm van vertwijfeling te raken, uit eigen vermogen de vertwijfeling opheffen. In een poging onszelf te zijn in relatie tot de oneindigheid stuiten wij op de existentiële noodzaak ons daarbij op God te betrekken; op de noodzaak de oneindigheid niet langer in de eindigheid (ook: onze eigen oneindige soevereiniteit) te zoeken.

Kierkegaard zélf verwoordt. Inderdaad oriënteert hij zich op het voorbeeld van Anti-Climacus, 'een Christen in buitengewone graad' (SKS NB 11: 204.a), en ziet hij zich als iemand (een 'dichter' slechts) die er voortdurend naar streeft Christen te worden door Anti-Climacus' hooggestemde idealen te realiseren (SKS NB 12: 9). Dat op deze plaats in eerste instantie aan dit pseudonieme geschrift wordt gerefereerd, als representatief richtpunt voor Kierkegaards eigen opvattingen aangaande 'de verdediging', is tevens gerechtvaardigd vanuit de wetenschap dat Kierkegaard zich ook in niet-pseudonieme geschriften in dezelfde bewoordingen uitlaat over deze thematiek. Hieronder wordt (onder meer) óók verwezen naar enkele van de in totaal 96 Opbouwende Toespraken en ook, min of meer uitvoerig, naar Wat de liefde doet. Een aantal Christelijke overwegingen in de vorm van toespraken (1847), dat onder naam van Søren Kierkegaard zélf gepubliceerd is. In dit laatstgenoemde werk worden overeenkomstige gedachten ontwikkeld, en ook dit boek vormt een 'onverbloemde' uiteenzetting van het ideale Christendom zoals Kierkegaard dat heeft gezien. 
Alleen door God kunnen wij werkelijk in rust en balans onszelf zijn, zoals wij anderzijds ook alleen door onszelf te zijn werkelijk tot God kunnen komen (SKS 11, 130).

De mens is dus steeds 'in wording'; hij heeft 'te zijn'. Vrij-zijn, het mij tot mijzelf verhouden verwijst naar de contradictie die de mens te zijn heeft. Dit is een belasting en opgave die een mens doorgaans uit de weg gaat. 'Men' wil niet zichzelf zijn, men wil de verantwoordelijkheden van het bestaan van zich afwentelen vanwege 'de duizeling van de angst' die dit met zich meebrengt. Dit kenmerkende 'niet zichzelf willen zijn', dit 'uit de weg gaan' van de fundamenteel-ethische eis van het zich tot zichzelf te moeten verhouden (bijvoorbeeld: door die verantwoordelijkheid af te wentelen op de een of andere redelijke zijnsordening) - dit 'niet zichzelf te willen zijn', ook in de zin van het 'vertwijfeld zichzelf willen zijn' noemt Kierkegaard kortweg: de vertwijfeling. De vertwijfeling is de 'ziekte tot de dood'. Het is een dodelijke ziekte, niet zozeer omdat die ('objectief') in de dood eindigt, per slot is voor een gelovig Christen de dood slechts een doorgang naar een nieuw begin, maar omdat de dood het doel is dat zieke zélf tracht te bereiken (SKS 11, 135). De zieke anonymus zoekt zijn eigen geest te doden; iets dat, hoewel hij in zijn vertwijfeling naar consistentie zoekt en zich voor alle hoop tracht af te sluiten, toch nooit helemaal zal lukken omdat een goede God de mens als geest geschapen heeft en hem er voortdurend aan herinnert dat hij als geest te zijn heeft. Om niet als anonymus te verkommeren - om aan de vertwijfeling te ontkomen gaat het er om niet in abstracties van de existentie weg te dromen, maar zijn gesitueerdheid actief-strevend op zich te nemen door die van vrijheid te doordringen.

Het gaat er om, door zich van de vertwijfeling in toenemende mate bewust te worden, in de eindigheid plaats te maken voor het oneindige. De bewustwording doet de koorts van de vertwijfeling in intensiteit steeds verder toenemen. Van zichzelf te weten vertwijfeld te zijn, te weten, niet zichzelf te zijn brengt de ziekte reeds op een hoger plan. Nog intensiever wordt het zodra men gaat beseffen vertwijfeld te zijn tegenover God. Pas door dit zondebesef kan men leren de zonde te gaan berouwen en wordt men pas eigenlijk ontvankelijk voor de vergeving waarin de vertwijfeling een einde kan vinden. De zonde is iets waartoe de heiden (die God niet kent) niet in staat is. Vergeleken met dit heidense perspectief zijn vertwijfeling en zonde een privilege; het is het bewustzijn ten achter te blijven bij de vrijheid waartoe je krachtens de macht die jou gesteld heeft bent opgeroepen. Zondig worden is een privilege van hen die van God gehoord hebben en die aan zijn roeping gehoor willen geven. De zonde doet beseffen dat dit nooit op eigen kracht zal lukken vanwege de oneindige 
afstand tot God. De oneindigheid van de ethische eis werkelijk voor God onszelf te zijn, impliceert de bewustwording van de eigen ontoereikendheid. Wij zijn als zondaars aangewezen op de genade van God, maar zodra wij dat eenmaal beseffen is de redding ook nabij. Want alleen door het geloof in zonde (door ons zelf te zijn in het bewustzijn zondaar te zijn) en vergiffenis (door het bewustzijn als zondaar aangewezen te zijn op de vergeving) kunnen wij ooit gerechtvaardigd worden.

\section{§3 De ergernis: de zonde is - vóór God}

We hebben gezien dat de bewustwording van de vertwijfeling die vertwijfeling intensiveert, maar ook dat die bewustwording de enige manier is om de ziekte te boven te komen. Ook is reeds aangegeven dat een belangrijk volgend stadium in dit dubbelzinnige bewustwordingsproces is dat men zich gaat realiseren, op grond van het besef als zelf op de oneindigheid betrokken te zijn, dat de vertwijfeling eigenlijk een zonde is; dat wil zeggen, dat men in toenemende mate gaat inzien dat de vertwijfeling een zonde is tegenover God. Zonde is, vóór God vertwijfeld niet jezelf willen zijn of vertwijfeld jezelf te willen zijn (SKS 11, 191).

De menselijke maat is doorgaans de maatstaf voor het zelfzijn. Dit komt het meest naar voren bij de trots - het vertwijfeld zichzelf te willen zijn; zichzelf te willen vinden of uit te vinden (te maken), zonder zich te riskeren in betrokkenheid op God; het is het op eigen wijze en uit eigen vermogen zichzelf te willen zijn. Aan het bewustzijn van de vertwijfeling ontbreekt de goddelijke maatstaf. Wat ontbreekt is het besef jezelf te zijn - vóór God; jezelf te zijn met God als standaard. Vóór God te mogen staan (om mijzelf op die schaal te mogen wegen) is een grote eer en maakt het zelf oneindig belangrijk. ${ }^{6}$ Dat het zelf geroepen is alleen voor God te komen, makkt het oneindig groot; ook als die schaal slechts uitwijst dat wij oneindig ver van God verwijderd zijn. Niet alleen (in relatieve zin) als kind voor je ouders te bestaan, of als volwassene voor de staat erkend te worden; maar als zelf vóór God - dát is de absolute standaard die het ethisch doel van het zelf aangeeft (SKS 11, 193).

$\mathrm{Nu}$ heeft de dogmatiek steeds beweerd, dat wat de zonde zo erg maakt is dat die bewust voor God begaan wordt, en dat men daarvoor in de hel gestraft

\footnotetext{
6 "En wat een oneindige realiteit verkrijgt het zelf niet, wanner het er zich van bewust wordt dat het voor God bestaat, wanner het een menselijk zelf wordt, dat God als maatstaf heeft." Over de vertwijfeling. De ziekte tot de dood (inleiding en vertaling A. Van Munster en A.P. Klaver), Utrecht/ Antwerpen, Prisma, 163) p. 91. (SKS 11, 193)
} 
wordt (SKS 11, 194). Volgens Anti-Climacus zit daar veel waarheid in; het is pas de ongehoorzaamheid vóór God (daarover gaat het in de Bijbel) die van de schuld een zonde maakt. Maar omdat het een dergelijk ongemakkelijke waarheid is, heeft 'Men' het beter gevonden zich hier van te distantiëren. 'Men' zegt: zonde is zonde; het is toch eigenlijk om het even voor wie of wat die zonde begaan wordt? ${ }^{7}$ Zo blijft de dogmatiek van de zonde een bron van ergernis en men tracht het 'vóór God' te relativeren. 'Men' twijfelt eraan of de definitie van de zonde niet al te spiritueel is? Zou een meer inhoudelijke en materiële bepaling van de zonde niet al toereikend zijn, en de zonde misschien zelfs beter benaderen (SKS 11, 195)? Ook hier luidt het antwoord van AntiClimacus volstrekt ondubbelzinnig ontkennend. 'Nee!' Want de zonde is een specificatie van de geest en daarom kan een definitie daarvan onmogelijk al te spiritueel zijn. 'Nee!' De definitie van de zonde noemt inderdaad geen concrete zonden als moord, diefstal en ontucht. De definitie bestrijkt echter álle vormen van zonde en natuurlijk vallen ook de genoemde overtredingen onder de ongehoorzaamheid tegenover God. 'Nee!' Indien men zich zou beperken tot materiële bepaling van de zonde dan vergeet men gemakkelijk dat alles heel goed helemaal in orde kan zijn - althans: volgens objectieve maatstaven - en dat toch het hele leven geheel en al in zonde kan zijn (zoals andersom, iets dat naar objectieve maatstaven gemeten afkeurenswaardig is, toch niet zondig hoeft te zijn). ${ }^{8}$ Bedenk wat Augustinus al bedoelde toen hij wees op de 'schitterende ondeugden' van de heidenen: een gewilligheid die - geesteloos of schaamteloos - onwetend blijft - of het verkiest onwetend te blijven - van hoe oneindig veel verder onze verplichting gaat om aan God te gehoorzamen (SKS 11, 197) ${ }^{9}$. Ieder geheim verlangen en denken staat onder de verplichting steeds bereid te zijn gehoor te geven aan zelfs maar de kleinste hint van God over wat Hij met deze mens - hier en nu - wil aanvangen. God is verborgen en niemand

\footnotetext{
${ }^{7}$ Kierkegaard wijst erop dat zelfs vanuit juridisch perspectief geldt dat een belediging van een ambtenaar in functie als een ernstiger vergrijp dan wanneer zo maar iemand beledigd wordt (SKS 11, 194).

${ }^{8}$ Dat ethische en juridische directieven (vanzelfsprekend) moeten worden toegepast op verstandige en billijke wijze, en krachtens een bepaald hermeneutisch denkvermogen (de phronesis of prudentia) en denkproces (het beraad, de bouleusis), is zelfs niet het begin van een toereikende oplossing voor het probleem dat Kierkegaard hier in navolging van Luther op het oog heeft. Het gaat hen niet om de kloof tussen regel en toepassing. Het gaat erom dat 'wat' van mij van God verwacht wordt - de liefde - dat die onmogelijk in willekeurig welke objectieve, algemene bepaling kan worden samengevat (om eventueel vervolgens prudent en in de geest van de wet te worden toegepast); dat die liefde daarentegen alleen in het geloof kan worden gerealiseerd. Goed en kwaad hebben geen objectief bestaan buiten de vrijheid van de enkeling - vóór God.

9 Augustinus, De stad van God, XIX, 25.
} 
mag zich aanmatigen hem te identificeren met de een of andere menselijke ordening. Wij moeten althans de bereidheid en openheid hebben daaroverheen te zien. Die bereidheid ontwikkelt men doorheen het zondebesef. Uiterlijke zonden - de zonden van het vlees - zijn uitdrukking van onze lagere begeertes; maar hoe vaak wordt niet een duivel uitgedreven met hulp van Beëlzebub en is het gevolg daarvan niet ernstiger dan het uitgangspunt (Luc. 11:15-16). Zo gebeurt wanneer iemand (bijvoorbeeld) zijn zonden uit zwakheid overwint met een legalistische eigengerechtigheid; of wanneer zo iemand in plaats daarvan opnieuw in zijn oude zonden vervalt. De normale, en gangbare gedachte is dat wij door ethische richtlijnen te volgen - door individuele, materiële zonden te vermijden; door deugdzaam te zijn -, dat wij ons daarmee gaandeweg verbeteren, en dat wij ons aldus met God kunnen verzoenen. Het tegenovergestelde is waar. Wij kunnen God slechts naderen door steeds zondiger te worden; door ons er in toenemende mate van bewust te zijn hoe oneindig ver verwijderd wij zijn van wat de gehoorzaamheid aan God van ons vraagt. Met het oog op de genezing moeten we niet trachten de kloof op ethische en rationele wijze te dichten; we moeten ons juist in alle eerlijkheid, dat wil zeggen, 'naakt' voor de kloof durven stellen om op vergiffenis en genade te mogen hopen. Door het 'Gij zult' van de Openbaring (óók: door de Koninklijke Wet van de Liefde; TS) wordt deze 'naakte' persoonlijkheid in het bestaan geroepen. Niet de inhoud van wat God van ons vraagt is beslissend, maar de 'formele' bereidheid God als richtsnoer aan te nemen (zonder nadere bepaling van wat dat in concreto betekent). Door het Christendom aannemelijk te maken, door na te laten het probleem bij de spirituele wortel te vatten, belandt men van de regen in de drup! De zonde is niet de onordelijkheid, ongeregeldheid van vlees en bloed in zichzelf (bijvoorbeeld: in relatie tot de natuurlijke essentie van de mens), maar het is de geestelijke instemming daarmee - ten overstaan van God. Wat niet uit het geloof voortkomt is zonde (Rom. 14:23). De zonde is niet de ondeugd. ${ }^{10}$ "En dit is een van de meest beslissende karakteristieken van het Christendom, dat het tegengestelde van zonde niet deugd is, maar geloof." 11 Het alternatief is een heidense visie die meent toe te kunnen met een menselijke, immanente standaard. Die heidense visie weet niet wat zonde is,

10 Hoewel Kierkegaard hem hier niet noemt, mogen wij ook denken aan Abraham (de vader van het geloof) die in zijn gehoorzaamheid aan God bereid was alle gebruikelijke zedelijke verplichtingen op te schorten. Naar algemeen-menselijke maatstaven gemeten is het offer van Isaac (Abraham's voornemen daartoe) niet te rechtvaardigen. Maar de zonde is: vóór God. En volgens déze definitie zondigde hij niet. Zie voor deze thematiek: Vrees en Beven (1843), Budel, Damon, 2007.

11 Kierkegaard, Over de vertwijfeling, p.94. 
al zegt men van wel. In het geloof tegenover God mijzelf te zijn, dát is het enige alternatief voor de zonde.

Maar de definitie van de zonde roept ergernis op. ${ }^{12}$ Dat de zonde 'vóór God' is, is een paradox; het is absurd. De specificatie 'vóór God' is ergerniswekkend; althans het is de mogelijkheid van ergernis. En dat de liefde verplicht is (een goddelijk gebod vormt), is voor het verstand (en voor de dichter) niet te behappen en 'aanstootgevend'. Maar door middel van deze ergernis houdt het Christendom zich de speculatieve wetenschap van het lijf; die ergert zich en kan er niets mee! De filosofie wordt door de paradox van de openbaring voor de keus gesteld: ofwel buigt zij nederig het hoofd voor het geloof (het offer van het intellect), ofwel volhardt zij in de vertwijfeling en de zonde die uit de ergernis spreken en gaat zij verder met haar pogingen het Christendom aannemelijk en 'relatief' te maken.

De enkeling vóór God is voor de filosofie niet bestaand. De speculant veralgemeniseert de enkeling tot het algemene, tot de mensheid in het algemeen. Het 'bei sich selbst sein' van Hegel is een geest of vrijheid die zich noodzakelijkerwijs in de geschiedenis ontwikkelt ${ }^{13}$; niet een door God gegeven mogelijkheid die alleen de enkeling in directe verhouding tot God kan waarmaken. Maar zo haalt Hegel niet alleen de mens, maar ook God naar beneden, namelijk door die in absoluut-geestelijke zin op te vatten. Zo is zonde gewoon zonde geworden (zonde ten opzichte van de natuur; de mensheid; de algemeenheid of de eigen gemeenschap). Zonde is hoe dan ook zonde (om het even tegenover wie of wat dan ook), maar niet meer 'vóór God'. Daar wil men vanaf, want het maakt het Christendom zo duister, streng en somber (SKS 11, 197). Zo zegt men althans, want in werkelijkheid is het Christendom juist te verheven voor hen die dit menen. De standaard van het Christendom is niet de mens maar God.

12 Cf. Luther, Verklaring van de brief aan de Galaten, hoofdstuk 3:6: "Als het verstand dat hoort, dat wij [van de zonde] gered worden door het geloof in Christus, hetgeen God als gerechtigheid aanrekent, ergert het zich dadelijk, raakt buiten zinnen en betuigt haar vijandschap tegen God en zegt: dan zijn dus de goede werken niets waard?"

13 Voor Hegel representeert de geschiedenis de idee van het recht in de zin van 'de verwerkelijking van de vrijheid'; de geschiedenis is een ladder (een paradijsladder) die de mensheid beklimt om bij God te komen (respectievelijk, een ladder die God afdaalt om bij ons te komen). Het is een trap die wij via de rede kunnen op- en aflopen en aldus in herinnering kunnen brengen. Maar voor de Reformatie gaat dit niet op. De geschiedenis is hier veeleer, zoals Macbeth het zo treffend zegt: "A tale told by an idiot, full of sound and fury, signifying nothing". Shakespeare, Macbeth, Act 5, scene 3, 26-27). De verplichtende lering die wij desondanks uit de geschiedenis trekken (het historisch besef) is een zaak van het eigen geweten. Luther: Hic historiarum usus est, quod docent conscientias. Weimarer Ausgabe, Bd. 25, 142.29. Voor dit thema, zie ook mijn dissertatie: Timo Slootweg, Geschiedenis en ethiek. Historisch besef in de tradite van Hegel, Heidegger en Derrida, Leende, Damon, 2000. 
Christus' waarschuwingen zich niet te ergeren, bevestigen de mogelijkheid van de ergernis, dat die er moet blijven; dat Hij zelf de paradox niet heeft willen verwijderen om de Vernunft Hure (Luther) van zich af te schudden. ${ }^{14}$ God heeft gesproken, maar de verdediging valt hem in de rede. Door de zonde te relativeren of door te zeggen: 'Nee, men hoeft het niet per se zo geëxalteerd op te vatten dat men de liefde persoonlijk van God zou krijgen. Is de liefde niet iets dat ons al van nature eigen is? Een verlangen naar de ander dat we zelf tot een vrijgevende liefde kunnen ontplooien, in overeenstemming met de hogere delen van de ziel kunnen brengen. Zo bezien is het eigenlijk een heel aannemelijke, zuiver immanente aangelegenheid.' 15 Verdedigen is 'aannemelijk maken'.

14 Anti-Climacus vergelijkt de ergernis van de heiden met die van een dagloner die op een dag door de keizer gevraagd wordt zijn schoonzoon te worden (SKS 11, 198). Als het iets kleins was geweest had hij het misschien geloofd. Maar dit is een exces! Nu wekt de uitnodiging slechts ergernis; hij heeft het gevoel dat men hem hier voor de gek houdt. Maar nu het Christendom: ieder mens is uitgenodigd in persoon voor God te komen. God heeft zijn zoon opgeofferd om ons daartoe uit te nodigen. De vertwijfelden die dat buitengewone aanbod niet kunnen geloven zijn geërgerd. Het aanbod van God is overdreven, onzinnig en vernederend. Summa summarum van alle menselijke verstandigheid is de gulden regel - ne quid nimis (in niets teveel; cf. Aristoteles' criterium van de deugdzaamheid; dat men daarbij steeds het juiste midden houdt) (SKS 11 200). Zo spreekt het verstand, maar het Christendom gaat daar juist ver overheen, tot in het absurde! Overigens kan hier gewezen worden op de overeenkomst met de kritiek van (vooral de 'vroege') Luther op de aanwezigheid van Aristoteles binnen de scholastieke Christelijke theologie (zie vooral zijn Disputatio contra scholasticam theologiam van 1517). In An den christlichen Adel deutscher Nation noemt hij Aristoteles 'de ergste vijand van de genade' en de Ethica het ergste boek dat hij ooit gelezen heeft, m.n. vanwege de absolute waarde die daarin wordt toegeschreven aan het slechts relatieve: de verstandigheid natuurlijk, maar ook het geluk en de vriendschap (ook vriendschap in politieke zin). Aristoteles' ethiek was, eerder dan allerlei futiele praktische ergernissen (die omtrent de aflaat bijvoorbeeld), de ware rede achter Luthers reformatie. De kritiek van Luther op de scholastiek (vooral op Thomas van Aquino) herhaalt in menig opzicht de kritiek van Augustinus op Pelagius; in menig opzicht ook, loopt die kritiek vooruit op de wijze waarop Kierkegaard met Hegel c.s. afrekent.

15 Dit in tegenstelling tot wat staat in 1 Cor. 2; 9: dat de liefde in geen mensenhart is opgekomen. De liefde is niet primair het werk en de verdienste van onze vrije, rationele wil (de wil is slechts een slaaf van de zelfliefde die zich tegen God richt). De liefde komt überhaupt niet van nature, als de relatief onafhankelijke kwaliteit van de menselijke schepping, maar alleen bij genade, 'ingegoten' vanwege de Heilige Geest, en dus direct van boven. Niet op kracht van eigen vermogen, door de autonome wil en in weerwil van het affect, maar slechts wanneer de ziel van de uitverkorene verlicht wordt door het goede affect van de goddelijke liefde kan men zich, bij wijze van antwoord daarop, bevrijden uit de gevangenis van de zelfliefde. Ook in Wat de liefde doet, Budel, Damon, 2007, benadrukt Kierkegaard steeds opnieuw dat de ware liefde - de liefde voor God en de naaste - pas door Christus, en dus met een schok (als plicht!) in de wereld kwam, en dat die ware liefde, zónder de Koninklijke Wet (vóór en ná Christus) nooit aan een mensenhart ontsprongen was. Alle natuurlijke liefdes van de heidenen - het beminnen, de vriendschap en het patriottisme - zijn slechts voorkeursliefdes die als zodanig een uitdrukking zijn van de liefde voor het zelf. Met de naastenliefde hebben zij in beginsel niets van doen. Ten overvloede: dat betekent natuurlijk niet dat ze verboden zijn en dat je moet ophouden je geliefde lief te hebben (nee, want ook je vriend is de naaste!), maar zij moeten door de christelijke liefde worden omgevormd en verbeterd. 
Het is een uiting van ongeloof en ergernis; alleen iets dat heel miserabel is moet verdedigd worden. "Maar nu het Christelijke! Ja, wie het verdedigt, heeft er nooit in geloofd. Gelooft hij dan is de bezieling van het geloof - geen verdediging, nee, ze is de aanval en de overwinning; een gelovige is een overwinnaar." 16

\section{§4 De socratische definitie van de zonde}

Ik wil nu twee alternatieve manieren beschrijven van hoe men het Christendom tracht aannemelijk te maken en te verdedigen tegenover de scepsis van ongelovigen. Twee manieren waaruit goed blijkt hoe schadelijk dit kan zijn; de verdediging is in feite gevaarlijker dan de aanval. Allereerst in deze paragraaf iets over de socratische definitie van de zonde (SKS 11, 201-209). Dan, in paragraaf vijf iets over de relativering van de zonde binnen het kader van de staat, het recht, de staatskerk en (tenslotte) het officiële Christendom.

De ergernis ten aanzien van het 'vóór God' drijft de mens ertoe de zonde iets anders te percipiëren, de zonde te relativeren door het 'vóór God' weg te verklaren. Over het algemeen geldt al dat een verklaring van de zonde het kwaad mitigeert; zoals gebeurt wanneer men een misdaad verklaart uit de sociaaleconomische achtergrond van de dader. Bij uitstek filosofische verklaringen van het kwaad leiden ertoe het te vergoelijken. Zo is voor Socrates de zonde onwetendheid. Van deze definitie wil Anti-Climacus de leegheid aantonen. Het defect van de definitie is (kortweg) dat niet wordt gevraagd naar de oorsprong van de onwetendheid. Gaat het om een oorspronkelijk niet-weten of is de onwetendheid pas later verkregen? Als dat laatste het geval is dan is zonde eigenlijk iets anders; een zonde van de wil - voor God: een wil die niet wil kennen en weten; een wil die niet wil ondanks dat die de waarheid kent.

Socrates wist niets van de zonde. Intellectueel beweegt hij van het weten naar de onwetendheid. Volgens het orakel was hij in dat opzicht zelfs de wijste van alle Grieken. Voor Kierkegaard is de socratische via negativa heel interessant. In het Afsluitend onwetenschappelijk naschrift bij de Wijsgerige kruimels (1846) geeft hij een definitie van de waarheid die sterk door Socrates geïnspireerd is: "De objectieve onzekerheid, volgehouden in de hartstochtelijkste innerlijkheid, is de waarheid, de hoogste waarheid die er voor een existerende bestaat. [...] De waarheid is dit waagstuk: met de hartstocht van de oneindigheid het objectief onzekere te kiezen." ${ }^{17}$ Ethisch echter, denkt Socrates negatief

\footnotetext{
16 Kierkegaard, Over de vertwijfeling, p. 99 (SKS 11, 200).

17 S. Kierkegaard, 'Afsluitend onwetenschappelijk naschrift bij de wijsgerige kruimels' in Denken en zijn, Meppel/Amsterdam, Boom, 1982, pp. 55-56.
} 
over onwetendheid, begint hij daarmee en beweegt hij zich in de richting van de kennis. Omdat Socrates de Openbaring aangaande de zondeval niet kent, blijft de zonde - de onwetendheid - bij hem ongefundeerd in de vrije wil. Daarom bestaat die bij hem ook eigenlijk niet. Zonde is onwetendheid van wat goed is, en voor die zonde ben je niet verantwoordelijk; eigenlijk is het geen zonde. Het goede kennen is het goede doen. Als je het goede kent, dan doe je het ook. En als je echt weet dat iets slecht is, zal je het niet doen.

Voor een Christen als Anti-Climacus echter, moet dit alles nog bewezen worden (SKS 11, 203). De natuurlijke mens, de heiden kan niet begrijpen wat zonde is. De zonde moet door God geopenbaard worden om daarvan bewust te kunnen zijn. Een menselijke verklaring van de zonde herleidt die tot iets anders; het is onwillekeurig een vergoelijking of verdediging van de zonde. De doctrine van de zonde echter, heeft ons uit de droom geholpen en ons meegedeeld dat de mens het heeft gedaan. De onwetendheid is gefundeerd in de wil; het niet willen weten en het niet willen überhaupt. Voor die kennis mag het Christendom nu niet meer de ogen sluiten!

Inderdaad is er een groot verschil tussen begrijpen en begrijpen; Socrates heeft dat goed gezien. En als iemand zegt dat hij het begrijpt en hij doet het niet, dan ontbreekt er kennelijk iets aan zijn begrip. Als iemand die zegt dat hij het Christendom begrijpt, het toch niet doet (het niet in praktijk brengt) als het erop aankomt, dan twijfelt men aan zijn oorspronkelijk begrip daarvan. Maar het is wel iets meer dan een slechts komisch, ironisch misverstand. Konden wij nog maar lachen zoals Socrates deed om de menselijke onnozelheid. Het probleem is echter dat Socrates geen dialectische specificatie geeft van de overgang van denken naar doen, van denken naar zijn. Daartussen staat, zoals het Christendom zegt, de wil en de koppigheid, en het dogma van de erfzonde. Ook vestigt het Christendom de aandacht op de enkeling, want zonder oog voor de enkeling lijkt de transitie op noodzakelijke wijze te verlopen, zoals in het systeem; en zoals overal in het moderne, heidense denken. Men zegt dan: 'Cogito ergo sum'; ik denk dus ik ben (Descartes). Het zijn zou al noodzakelijkerwijs uit het denken volgen. Maar juist dat klopt niet, en aan de Christenen is dat bekendgemaakt.

Het zijn van de mens heeft meer met zijn wil van doen dan men wil erkennen. Tussen begrijpen en doen zit vaak wat tijd. Tijd voor de wil om te bepalen wat die van het denken vindt. Als het de wil niet bevalt, dan wacht die nog even met te doen wat het denken aangeeft ('ik zal er morgen nog eens naar kijken'; SKS 11, 207). En wanneer het begrip door zo te talmen eenmaal voldoende verduisterd en verwaterd is, dan komen de wil en het begrip als vanzelf al beter overeen. En gaandeweg sluit het begrip zich naadloos aan bij wat de wil wil. De ratio is 'de hoer van de wil'; de wil zet het denken naar zijn hand. 
De Grieken (en na hen al de Griekse pseudochristenen) hadden de moed niet te zeggen dat iemand willens en wetens kwaad kan doen. En dus zeggen zij: de zonde reflecteert een misverstand. In zekere zin is dit juist: wij kunnen de zonde niet uit onszelf begrijpen. Want wij zijn in de zonde en die zonde tast ons begrip aan. Het begrip van de zonde is een immorele vergoelijking, een excuus van dat wat niet te excuseren valt. Een voortzetting van de zonde. Daarom kan men zich niet anders bewust worden van het kwaad dan via een Openbaring van God. ${ }^{18}$ Niet begrijpen van, maar geloven in de Openbaring is de manier om bewust te worden van de zonde. Het verhaal van de oerzonde zegt: niet dat de mens niet goed begrepen heeft te moeten gehoorzamen (God is duidelijk geweest!), maar hij wil het niet begrijpen, en hij wil niet luisteren (SKS 11, 208). Deze beschuldiging aan het adres van de mens - dat de leer van de zonde vóór God niet zomaar begrepen kan worden zonder die weg te verklaren maakt het Christendom tot een ergernis. Men denkt van zichzelf best te weten niet perfect maar zondig te zijn, en voor die wetenschap de Openbaring niet nodig te hebben. Het Christendom heeft daartegen gezegd (en dat mag dus nu wel verondersteld worden bekend te zijn): 'nee, dat weet je niet, de zonde gaat veel dieper dan je denkt (het is geen onwetendheid), en dat kan niet 'begrepen' en gepeild worden anders dan door de openbaring'. Nu, als Christen niet te begrijpen wat in de Openbaring geleerd is, dat is de eigenlijke zonde; geleerd te hebben van de Openbaring wat zonde is, om dan toch, vóór God in vertwijfeling niet jezelf te willen zijn (in zwakheid), of vertwijfeld jezelf te willen zijn (in trots en koppigheid). Het is zondig om als Christen nog, vast te willen houden aan de definitie van de zonde als onwetendheid. Het is een vrucht van de boom der kennis. En, zoals Karl Barth schrijft in zijn Kirchliche Dogmatik, toen de mens zondigde door van die boom te eten, werd hij ethicus. ${ }^{19}$

18 Cf. Luther, Vorlesung über den Römerbrief - 1515 / 1516, Ficker II, 1xixi, 10 en lxvii, 31. Wij moeten op grond van een bevestiging van de Openbaring tot onszelf bekennen wat wij daarvoor niet wisten, namelijk dat wij zondaars zijn.

19 Cf. Karl Barth: Kirchliche Dogmatik IV/1, p.497: "Als der Mensch sündigte, wurde er Ethiker." Cf. Luther, Heidelberger Disputation; WA 1, 353-374; These 1 e.v.. Onder invloed van de slang interpreteert Eva de waarschuwing van God ("als je daarvan eet, zul je onherroepelijk sterven"; Gen. 2,17) als een verbod - als wet. En deze wet verlokt haar tot de overtreding. Heeft de mens zich eenmaal een overzicht over goed en kwaad verschaft, dan moet hij met deze kennis voortaan verder leven. Maar middels de maatstaf van de wet (regels en geboden) kan de levende, persoonlijke ontmoeting met God (en de naaste) niet plaatsvinden. Door de wet komt slechts de kennis van de zonde (Rom. 3,20); want krachtens de wet moet Christus - het levende woord van God - sterven (Joh. 19,7). Bij Kierkegaard is het de angst voor de vrijheid die de overtreding inleidt; het eten van de boom der kennis is een vluchtweg. Voor Kierkegaards interpretatie van Genesis, zie: Timo Slootweg (ed.), In de schaduw van de Boom der Kennis. Ethiek en de zondeval, Budel, Damon, 2006, pp. 150-176. 


\section{\$5 De Staat en het officiële Christendom}

Ook uit zogenaamd 'Christelijke' opvattingen over de staat en uit de opvattingen van het officiële Christendom spreekt een nauwelijks verholen ergernis over het vóór God van de zonde. Niet je ouders, of de staat, of de kerk, maar alleen God is de absolute standaard waaraan wij gemeten worden. Het individu is primair ten opzichte van de groep omdat de 'ethiek' van de enkeling voortkomt uit een directe verhouding tot God. God is degene voor wie als wij enkeling zijn uitgenodigd te verschijnen. Wij moeten het riskeren te trachten zonder enige reserve vóór God onszelf te zijn; dat is de echte Christelijke herö̈ek waartoe wij zijn opgeroepen (SKS 11, 118). Voor het verstand is dit echter een dwaasheid en een ergerlijk exces; het is een brug te ver. Daarom tracht men God te 'accommoderen', aan een algemene morele code, die van de staat - de burgerlijke of staatrechtelijke Gesinnung (de huwelijkse liefde; de Rechtschaffenheit; het patriottisme) - gelijk te schakelen om aldus de zonde wat te relativeren en draaglijker te maken; glad gepolijst door het sociale leven, courant en uitwisselbaar te zijn als een geldstuk (SKS 11, 151). Maar de zonde staat tegenover het geloof, en niet tegenover de deugd.

Zo valt ook te begrijpen waarom er niet gesproken kan worden van een eigenlijk Christelijke staats- of rechtsfilosofie. Zoiets kan onmogelijk bestaan; de secularisering van beide is een in essentie Christelijke beweging. Het is de verdienste van Luther geweest de politiek (en ook de wetenschap) te 'bevrijden' van het religieuze en ethische (en andersom; dat hij het religieuze heeft vrijgemaakt van de politiek). Hij heeft de politiek en het recht hun eigen wereldse wet en natuur toegewezen; een in essentie 'zondige' natuur die niet geïdentificeerd kan worden met de moraal van de Bergrede. De staat moet omwille van de barmhartigheid, onbarmhartig zijn, en niet het kwade met het goede willen vergelden. De staat moet het onrecht wreken (niet dulden en lijden), hoewel anderzijds de onbarmhartigheid - als middel of instrument tot de liefde - het doel ook niet in de weg mag staan.

Kierkegaards staatsopvatting is een realistische en instrumentele. Zijn opvatting lijkt ook in menig opzicht op die van Kant door wie hij sterk beïnvloed is geweest. En zelfs de politieke filosofie van Locke en Hobbes is hier niet ver weg. De taakstelling van de staat is in essentie beperkt tot het veiligstellen van de 'negatieve vrijheid' van individuen, om de 'positieve vrijheid' nadrukkelijk aan het gescheiden terrein van ethiek en religie te laten. Kierkegaard voelt niets voor de leer die de latere Luther over de twee rijken heeft ontwikkeld; daarmee heeft hij zijn eigen reformatorische beginselen vertroebeld. Net als het kwaad zelf, is ook de staat is niet zomaar een godgegeven scheppingsorde. 
Een goed geordende staat is (hooguit) een moreel neutrale organisatie; een die aan de moraliteit in eigenlijk zin niet toekomt.

Een goede staat is rechtvaardig in de zin dat die 'ieder het zijne geeft'. Dit principe van rechtvaardigheid vormt (volgens de traditie) de belangrijkste grondslag van het recht. De klassiek geworden opvatting van Ulpianus in de Digesten $(1,1,10)$ van het Corpus Juris Civilis zegt: de gerechtigheid is de vaste en constante wil om ieder zijn recht toe te delen (suum cuique tribuere). De gerechtigheid komt op voor het eigen-dom; ze bepaalt wat ieder het zijne mag noemen. Als iemand niet het verschil respecteert tussen mijn en dijn dan oordeelt en straft de staat. Zo waarborgt ze de veiligheid waarin ieder het zijne heeft en waarin ieder zijn recht op het eigene kan doen gelden; waarin ook iedere burger zijn recht kan halen (zichzelf rechtens kan handhaven). En als een burger van zo een goede staat niet meer dan het zijne zoekt, dan zal de rechtvaardigheid hem niets verwijten, zodat een ieder toekomt wat het zijne is. Dat geldt dus voor de staat en het recht. In Wat de liefde doet (1847) laat Kierkegaard zien dat dit helemaal niet in overeenstemming is met de kenmerken van de Christelijke liefde. ${ }^{20}$ 'De liefde zoekt het hare niet' (cf. 1 Kor. 13,5). In liefde is er geen verschil tussen mijn en dijn. En in de liefde ben je er niet op uit jezelf of het eigene te handhaven en te behouden. Want liefde is juist overgave en zelfverloochening; want als je het jouwe zoekt dan is dat juist zelfliefde.

Omdat de juridische wetten van een staat slechts op uiterlijke, dwangmatige wijze worden gehandhaafd, kunnen zij überhaupt niet wetgevend zijn voor de subjectieve motivatie van een handeling. De staat is een noodzakelijk kwaad om door uitoefening van macht en geweld het lagere egoïsme in de mens te bestrijden en binnen de perken te houden. Maar het is een pseudoreligieuze mystificatie wanneer het gesublimeerde egoïsme in de politiek voor naastenliefde gehouden wordt. Het is slechts een 'hoger egoïsme' dat mensen in een staat bijeenhoudt. ${ }^{21}$ Alleen uit eigenbelang ben ik ertoe bereid mijn vrijheid tot op zekere hoogte te beperken en aan de overheid over te dragen. Een staat opzetten en organiseren is dan ook een klus die geen speciale wijsheid verlangt en die (zoals Kant zegt in Zum ewigen Frieden) heel goed door 'slimme duivels' verricht kan worden. Het veronderstelt per slot van rekening slechts inzicht in het mechaniek van de egoïstische natuur van de mens; het gaat erom die tegen zichzelf uit te spelen zodat de destructieve werking daarvan zoveel mogelijk geëlimineerd wordt.

20 Søren Kierkegaard, Wat de liefde doet, Budel, Damon, 2007, pp. 287-290 (SKS 9 263-266).

${ }^{21}$ Over de staat als 'hoger egoïsme': Pap. XI 2 A 108, 111. 
Verder dan een modus vivendi in vrede en veiligheid reikt de staat niet; hetgeen vanuit het perspectief van Hegel een teleurstellende, onaanvaardbare conclusie moet zijn. Volgens Hegel is de staat niet slechts een neutraal instrument voor de soevereiniteit en vrijheid van individuen, maar hij is zelf de belichaming daarvan. Het recht is de verwerkelijking van de vrijheid (het is de Idee, niet slechts het Begrip van de vrijheid). De ware soevereiniteit vinden wij niet in de private morele sfeer, maar in de zedelijkheid van het leven in de staat; doordat het individu zich identificeert met de substantiële ${ }^{22}$ algemeenheid van het publieke leven. Een dergelijk sterk belang hecht Kierkegaard zeker niet aan de staat. Te denken dat men door in de staat te leven een moreel beter mens zou worden - afgehouden van het kwaad en deugdzaam, tot het goede opgeleid -, het idee dat men in een staat wordt opgevoed tot wat zijn bestemming is - als 'gezelschapsdier' 23 - is voor Kierkegaard even twijfelachtig als te denken: "dat men zich in een tuchthuis zou kunnen verbeteren" 24 . Hooguit levert de staat de voorwaarden voor een negatieve vrijheid, die van instrumenteel belang is voor de morele autonomie en positieve vrijheid van de enkeling - vóór God.

De mens is geen politiek wezen zoals de klassieke en de moderne Grieken gedacht hebben. En de staat is ook zeker niet 'de verwerkelijking van de vrijheid', zoals Hegel en de hegelianen menen. De staat drijft de duivel uit met Beëlzebub. Het is daarom (zoals ook reeds Luther onderkende) eerder een duivelswerk te noemen. De gehoorzaamheid aan God is niet te vergelijken met de gehoorzaamheid aan een abstracte, algemeen geldige wet. God openbaart zich niet in voor alle tijden, vooruit te berekenen wetten, en vanuit dat perspectief is ook het recht (en de rechtsgeleerdheid) een vrucht van de boom der kennis door welke de mens zich verder van God verwijdert.

Tot het geweten heeft de staat geen toegang en hoort daar ook buiten te blijven; niemand kan tot het geloof gedwongen worden. De waarheid van het

${ }^{22}$ Het substantiële is bij Hegel primair. In vergelijking daarmee is het individu slechts een Accidens. Cf. $\$ 145$ van Hegel, Grunlinien der Philosophie des Rechts.

${ }^{23}$ Idem, §153: "Das Recht der Individuen für ihre subjektive Bestimmung zur Freiheit hat darin, daß sie der sittliche Wirklichkeit angehören, seine Erfüllung indem die Gewißheit ihrer Freiheit in solcher Objektivität ihre Wahrheit hat, und sie im Sittlichen ihr eigenes Wesen, ihre innere Allgemeinheit wirklich besitzen." En met instemming haalt Hegel vervolgens een Pythagoreër aan die op de vraag van een vader naar de beste manier om zijn zoon op te voeden antwoordt, dat hij hem moet opvoeden tot een burger van een staat met goede wetten. - Overigens is de gedachte van het politieke dier (zoon politikon) waarnaar hier verwezen wordt afkomstig van Aristoteles, Politica 12 $1253 \mathrm{a}$.

${ }^{24}$ Cf. Pap. XI 2 A, 108. 
geloof (de liefde) is subjectief ${ }^{25}$ en de staat kan niets anders doen dan de existentie, waarin de waarheid zich kenbaar kan maken, 'vrij te laten'. De staat bemoeit zich slechts met het uiterlijke en materiële. Het leven in een staat dient slechts het (relatief) hogere zelfbehoud en niet de religieuze zelfgave vóór God. En daar waar de staat iets meer wil doen dan voor vrede en veiligheid te zorgen, en die zich door een verdergaande bevoogding of in het kader van een staatskerk (zoals in de tijd van Kierkegaard) met zielzorg en religie bemoeit, daar dreigt het individu en zijn enkelvoudige ethiek ten onder te gaan. Religie is de zaak van de enkeling vóór God, en de bevoogdende staat en het instituut van de staatskerk, of een kerk zoals Hegel die ziet - een kerk die in dienst van de staat functioneert en in verregaande zin bij de staat aan de ketting ligt - staan in de weg dat deze verhouding en de sprong van het geloof daadwerkelijk tot stand komen.

De latere Kierkegaard richt zich steeds directer en openlijker tegen het officiële Christendom en de (Lutherse) staatskerk van Kopenhagen. ${ }^{26}$ De georganiseerde kerk staat in de weg van de geloofskerk of de 'onzichtbare kerk', zoals Kierkegaard dat een enkele keer noemt, die eigenlijk met het corpus mysticum bedoeld wordt. De scheiding van kerk en staat zou beide tot voordeel strekken; áls dat er tenminste toe zou leiden dat in de kerk het radicale Christendom gepreekt zou worden. De verzoening met God is pas mogelijk door de paradox van zonde en vergiffenis; die vereisen dat de enkeling zichzelf 'terughaalt' (verzamelt) uit het immanente en relatieve; dat hij zijn voorkeursliefdes opgeeft of tenminste relativeert. De staatskerk maakt het de gelovige te gemakkelijk en comfortabel. De kerk ontneemt de gelovige zijn individuele verantwoordelijkheid tegenover God. Zijn verantwoordelijkheid is beperkt tot de niet voldoende ernstige, slechts uiterlijke verplichtingen tegenover de gemeenschap en de staat. Dat is ook precies wat Hegel bedoelde met die onpersoonlijke Sittlichkeit. In die zin en tot zover kan en mag de Christelijke Gesinnung van de naastenliefde bijdragen aan het voor de staat

25 De waarheid is subjectief in de zin van de innerlijkheid, de sprong van het geloof en de beslissing, niet in romantische of dichterlijke zin natuurlijk. "Had Pilatus niet objectief de vraag gesteld wat de waarheid was (Joh. 18,38), dan had hij Christus nooit laten kruisigen. Had hij het subjectief gevraagd, dan had de geestdrift van de innerlijkheid in hetgeen hij in de voor hem staande beslissing in waarheid moest doen, hem verhinderd onrecht te doen." Cf. 'Afsluitend onwetenschappelijk naschrift tot de Wijsgerige kruimels', in Denken en Zijn, p. 81. Zie ook: Oefening in Christendom, SKS 12, 200-203.

26 Zie hiervoor: Søren Kierkegaard, Schotschriften tegen gevestigde kerkelijkheid, vert. W.R. Scholtens, Baarn, Ten Have, 1980. Het boek bevat de bijdragen geschreven in zijn laatste levensjaar (1854-1855), aan 'Het Vaderland' en 'Het Ogenblik'. 
benodigde ethos. Voor zover echter het gebod van de naastenliefde wordt opgevat in een meer oorspronkelijk-transcendentale zin, in de vrije, augustiniaanse zin van 'hebt lief en doe wat je wil', daar gaat het Christendom voor de staat een brug te ver. Daar berust het ineens op een irrationeel misverstand en staat het de overheid vrij om wanneer dat nodig is in te grijpen. ${ }^{27}$ Daarom is voor Kierkegaard de seculiere staat uiteindelijk te verkiezen, omdat die door de burgerlijkheid te bevorderen nog het beste uitzicht biedt op een authentieke religiositeit. De desacralisatie van de natuurlijke, de sociale en de politieke wereld, de ontkerkelijking en de secularisatie (vruchten van reformatie en Verlichting) bieden paradoxaal genoeg de unieke gelegenheid de religiositeit van de enkeling te bevorderen. Let wel: het is juist ter wille van de naaste dat hij de absolute eis van het vrije geweten stelt; het vrije en persoonlijke geweten dat in de staat, en door al die objectief-geestelijke instituties en 'bemiddelingen' geen kans meer maakt.

Het is uiteindelijk de godsvreze die Kierkegaard ertoe beweegt het 'slechts' profane karakter van alle aardse ordeningen te benadrukken. God is de levende, onberekenbare, in Zijn raadsbesluit verborgene en daarom altijd verrassende Ander die zich slechts kenbaar maakt in de roeping van het ogenblik. De Franse Revolutie heeft de existentie bevrijd door ontbinding van allerlei gevestigde, quasi-goddelijke hiërarchieën (die eigenlijk slechts betrekkelijk zijn). Het verlies van dit objectieve kader stelt de religie voor de uitdaging en de mogelijkheid, échte broederschap te verwerkelijken; een gelijkheid van allen, als enkeling voor God en zo ook, gelijk verantwoordelijk in liefde voor de naaste. Daarbij bergen de staat, de gemeenschap en vooral ook de democratie het gevaar de enkeling in het groepsverband, in de onverschilligheid, de gelijkschakeling en de abstractie ('het socialisme') te doen ondergaan. Democratisering impliceert een ééndimensionale hang naar nivellering (een slechts aardse gelijkheid) als gevolg waarvan de enkeling gemarginaliseerd wordt. Zo stelt de democratie je voor de keuze: ofwel ga je op in de anonieme reflectie, het publieke debat en de massa, ofwel kies je jezelf als enkeling door je daaruit te verzamelen. Ware gemeenschappelijkheid, in eigenlijke zin de naaste lief te hebben, is pas mogelijk door individuatie en zelfverloochening (alleen door jezelf te verliezen in het er als zelf te zijn voor de naaste zul je jezelf vinden). In relatie tot de massa zul je jezelf verliezen in een slechts berekenende,

27 Voor Hegel is het Christendom slechts tot op zekere hoogte waar en het is als zodanig voor verbetering vatbaar. Zie bijvoorbeeld Hegels ontluisterende verwerking van het Christendom, en de haat waarmee hij het stichtelijke achtervolgt, in zijn Grundlinien der Philosophie des Rechts; zie daarin zijn voorrede (NB met een beroep op Luther!) en vooral ook $\$ 270$, over kerk en staat. 
begerende liefde (een voorkeursliefde van mens tot mens, de Anerkennung 28 - zonder God als tussenbepaling). De massa is het bereik van de gelijkheid in de zin van de wederkerigheid (de ander is hier een ander zelf; de liefde een sigaar uit eigen doos). De jaloezie is uiteindelijk het enige wat ons nog bindt.

\section{$\S 6$ Mens erger je niet!}

Zonde is niet slechts iets negatiefs; het is niet zelf iets; het is slechts 'een ten achter blijven bij' (SKS 11, 209). De orthodoxe dogmatiek heeft deze gedachte terecht als pantheïsme afgewezen. De speculatie verandert het positieve van de zonde in het slechts negatieve. Hegel negeert het kwaad als kwaad (het is slechts het 'nog niet' van het systeem, dat zonder het dialectische moment van dit relatieve kwaad niet denkbaar is). Het berouw wordt dan slechts zoiets als 'de negatie van de negatie'. Het berouw verloopt automatisch en logisch ('twee nonnen heffen elkaar op'; krachtens de dubbele negatie), zonder enige, werkelijk persoonlijke bemoeienis van de enkeling.

De zonde is geen privatie, en er is ook geen verzoening van natuur en genade. De zonde mag niet worden gerelativeerd door er iets anders van te maken dan een kwaad, tegenover God. Juist daarom moet aan het geloof worden overgelaten of men vasthoudt aan de positiviteit van het kwaad. Laat men het niet willen verdedigen door redenen te geven; het Christendom is een paradox. Dat wat geopenbaard moet worden kan niet beredeneerd. Redenen aanvoeren betekent het positieve van de zonde (als wilsbeschikking) te negeren en het berouw weg te moffelen als 'de negatie van de negatie'. God en mens mogen niet, middels de algemeenheid samengevoegd worden in het systeem. Daarom ook de paradox, de onwetendheid en het geloof; het is het aanstootgevende van het Christendom dat het beoogt te beschermen tegen de dodelijke omhelzing van de speculatie, die het wil verdedigen. ${ }^{29}$

\footnotetext{
${ }^{28}$ Het strijdende en lijdende karakter van het Christendom (het Christendom van het kruis) wordt afgeschaft als wij toelaten dat de dialectiek de strijdigheid ten opzichte van de wereld (ook: de wereldse compassie) opheft. Een aldus gevestigd Christendom leert ons dan dat wij ons moeten herkennen in iedere ander, zoals ieder ander zich in mij moet leren herkennen. Dit apaiserende ethos van Anerkennung echter continueert de vertwijfeling, en sublimeert die zelfs tot een hoger, demonisch niveau.

29 'Als het dus waar is dat zoveel 'Christenen' in deze tijd het Christendom laten glippen, hoe zou dat dan komen? Komt dat niet omdat de mogelijkheid van de ergernis hen ontglipt, dat verschrikkelijke: 'gelieve op te merken!'” Toen het Christendom ter wereld kwam was de ergernis evident. Maar nu het Christendom al sinds eeuwen min of meer getrouwd is met het menselijk verstand, nu Christendom en verstand elkaar tutoyeren, moet het er weer de aandacht op leren vestigen dat het inderdaad tegen het verstand strijdt. "Alleen de mogelijkheid van de ergernis (het tegengif tegen
} 
De verdediging echter, is een uitdrukking van ergernis en ongeloof. Want hoe kan een zonde die zo absoluut is - dat wil zeggen: vóór God is - nog ooit worden weggenomen, zoals het Christendom zegt dat wij moeten geloven? Deze paradox van zonde en vergiffenis en verzoening valt zo niet te begrijpen, en het is juist daarom dat de speculatie er voortdurend op uit is het 'positieve' van de zonde iets minder positief maken, en de vergiffenis iets minder bovennatuurlijk.

Vanwege het paradoxale en ergerniswekkende karakter ervan is het zondebesef iets heel uitzonderlijks. Alleen in het Christendom vinden wij het soms. Pas door de Openbaring worden wij transparant voor onszelf; worden wij pas eigenlijk onszelf als zondaars. De meesten echter zijn zo ver van het goede (het geloof) verwijderd dat wij ze nauwelijks nog vertwijfeld kunnen noemen. Maar het Christendom vereist nadrukkelijk een zondebesef ('makk anders van de kerken maar danszalen!'). Het besef van zondig te zijn, het steeds verder opvoeren van dit zondebesef, is noodzakelijk voor het berouw; en zonder berouw kan er geen vergeving (genade) zijn. Dat zondebesef vereist een geest, die geest hebben wij allemaal meegekregen, en onze geesteloosheid in zake het zondebesef hebben we dus helemaal aan onszelf te danken. Het is onze eigen schuld als wij tot de zonde in eigenlijke zin niet doordringen. De exclusiviteit van het zondebesef van de Christenheid - de heroïsche zeldzaamheid van het zondebesef - is in het Christendom verkwanseld. Het zijn louter woorden geworden; een 'directe mededeling' die als zodanig aan de existentie voorbijgaat en die nu door de eerste de beste professionele dominee kan worden uitgedragen. De roeping is überhaupt iets heel gewoons geworden en van iedere mystificatie en uitzonderlijkheid ontdaan. Daarbij is het probleem niet dat niemand het opneemt voor het Christendom (ook niet dat er niet genoeg dominees zijn), maar dat al diegenen die het voor het Christendom opnemen dat op een dusdanig redelijke en aannemelijke manier doen dat niemand er uiteindelijk nog veel waarde aan hecht. Het hoogste en heiligste zijn nu zo gewoon en goedkoop geworden dat men best heel goed zonder kan. Juist omdat men van zijn eigen gebruiken iets heel gewoons heeft gemaakt, moet en kan het nu ook verdedigd worden. Want alleen iets dat eindig is, kan verdedigd worden!

\footnotetext{
het slaapdrankje van de apologetiek) is in staat om degene die ingeslapen is wakker te maken, is in staat om degene die betoverd is terug te roepen, zodat het Christendom weer zichzelf is. [...] Wee degene die het geheim van het geloof verraad en verbreekt, die het verdraait tot een publieke wijsheid door de mogelijkheid van de ergernis weg te nemen. Wee degene die het geheim van de verzoening zou kunnen begrijpen zonder iets van de mogelijkheid tot ergernis op te merken." Kierkegaard, Wat de liefde doet, pp. 218-219 (SKS 9, 198-199).
} 
Geloven is verliefd zijn. Iemand verdedigt zijn liefde niet door drie goede redenen te geven. Daarmee maak je juist pijnlijk duidelijk niet echt verliefd te zijn (SKS 11, 216-217). Het beredeneren van het nut van het bidden, het maatschappelijk nut van het geloof, de verklaring van de zonde e.d. zijn evenzoveel uitingen van ergernis en ongeloof. De verdediging is gericht tegen de onwetendheid; alsof het Christendom een doctrine is die kan worden 'bijgespijkerd' alsof het gaat om een inburgeringcursus in normen en waarden. Het is echter geloof. Het Christendom wordt alleen door het geloof gerechtvaardigd, en aldus kan de onwetendheid juist in het voordeel van het geloof werken. De zonde valt niet te begrijpen zonder die te negeren; om in berouw voor onze zonde voor God te verschijnen behoeven wij slechts het geloof in de openbaring. Het is verraad en ontkenning van het geloof als men het wil beredeneren en men de zonde tracht te peilen op rationele wijze.

Het is de ergernis aan het Christendom die ingeeft dat men het gaat verdedigen. Men bedenkt bijvoorbeeld de een of andere variant op de 'natuurlijke theologie' en baseert zich op een zogenaamde 'algemene Openbaring' (een 'analogie van het Zijn'). Op deze weg onderscheidt men allerhande scheppingsordeningen (het huwelijk; de burgerlijke samenleving; de staat; het recht - nationaal en internationaal) en men meent dat in de wetten van de natuur (Lex naturae), en in het menselijk geweten de liefde van God in essentie al tegenwoordig is. Maar deze idee van een analogie tussen God en mens gaat voorbij aan de oneindige afstand - de kwalitatieve differentie - tussen beide. Een mens is als enkeling geroepen om te doen waarvoor hij verantwoordelijk is (alleen zo is hij imago Dei). Een 'horizontale' interpretatie van de zonde bedoelt die te relativeren; die bedoelt de zonde te relateren aan de eindigheid (die relatief is). Want er is geen continuitteit tussen natuur en genade, tussen rede en Openbaring.

Geconfronteerd met het verraad van hun idolatrie - de zonde is vóór God en de vergiffenis en de genade krijgen wij niet van nature maar die komen van boven - kan de vertwijfeling (de trots en de koppigheid - het 'vertwijfeld zichzelf te willen zijn') zich uiteindelijk zelfs tot een demonische ontkenning van zonde en vergiffenis ontwikkelen. De zonde zoekt zich te consolideren in een logische consistentie die iedere verleiding die er nog van het goede kan uitgaan wenst af te wijzen (SKS 11, 220). Maar deze consistentie leidt tot de duivel. De tendens culmineert dan in een agressieve uitval tegen het Christendom en in een brutale ontkenning daarvan. Maar gaat het aldus van kwaad tot erger. En komt men niet door de bewustwording van de eigen vertwijfeling (door de Openbaring) alsnog tot inkeer, dan zijn we eigenlijk helemaal klaar met deze zogenaamde verdedigers. Want zij hebben zich nu door hun flagrante en brutale 
ontkenning tegen de Heilige Geest uitgesproken (zij zijn niet meer ontvankelijk voor de helende werking van de Geest). Zij verdienen, meer dan wie, onze barmhartigheid. Maar zij zijn als verdedigers een vijfde colonne, en bij nader inzien zijn het vermomde duivels die zichzelf nu als zodanig ontmaskerd hebben.

\section{\$7 Kierkegaards bewapende neutraliteit tegenover de Christenheid}

Het bezwaar dat men nogal eens tegen het Christendom opwerpt is dat het mensonvriendelijk en zelfs onmenselijk zou zijn. Het Christendom werd ook wel odium totius generis humani genoemd ('iets dat vijandig is ten opzichte van de gehele menselijk soort ${ }^{30}$ ). Volgens Kierkegaard is deze aantijging in zekere zin helemaal in overeenstemming met de waarheid. Die bevat in ieder geval meer waarheid dan de verdediging die men hier gewoonlijk tegenin beuzelt. Door ter verdediging van het geloof te argumenteren, bewijst men eigenlijk het tegendeel, dat er naast het woord van God nog een andere, natuurlijke Openbaring zou bestaan. De beste verdediging tegen deze idolatrie is niet te lang naar deze slang te kijken. Want het gevaar is dat die je hypnotiseert met zijn praatjes, om je vervolgens te bijten en te vergiftigen. Het is maar het beste deze slang dood te slaan zodra die in zicht komt en die zo snel en resoluut mogelijk van je af te wijzen, voordat het te laat is.

Van een Christen mag verwacht worden dat die een zekere bewapende neutraliteit inneemt. Zo heeft Kierkegaard ook zijn eigen positie als Christelijk schrijver in de Christenheid willen betitelen. ${ }^{31}$ Zeker meent hij dat een Christen zich tegenover een heiden moedig als Christen moet durven bekendmaken. Maar tegenover de Christenen van de Christenheid, tegenover hen die zeggen het voor het Christendom op te nemen (en wier Christendom hierboven besproken is), heeft hij, juist ter verdediging van het Christendom, heel zorgvuldig en moedig een bewapende neutraliteit willen bewaren. Juist in dit ethos, deze ethische reserve is het waar Christelijk martelaarschap gelegen. ${ }^{32}$

30 Tacitus, Annalen XV, 44.

31 'De bewapende neutraliteit of mijn positie als Christelijk schrijver in de Christenheid.' 1848; oorspronkelijk afgedrukt in de Papirer X 5B 105-114; SV 1 13, 489-509; SKS 16 (nog niet uitgegeven).

32 In bovenstaande bespreking van Anti-Climacus' Ziekte tot de dood zagen wij reeds dat het ware Christendom zich kritisch en gereserveerd opstelt ten opzichte van het spiritueeel-materialisme van de christenheid. De paradox is dat een waar Christen geen identiteit heeft. Christen-zijn is altijd opgave; het is het jezelf steeds opnieuw en oorspronkelijk verhouden tot de indirecte mededeling (door God) van het gebod van de liefde. Met het oog daarop streeft ook Kierkegaard ernaar zichzelf te worden (Christen te worden) door zichzelf te verliezen en louter opgave te worden. 
Een waar of 'ideaal' Christen moet zien stand te houden tegenover al diegenen die zich apodictisch 'Christen' durven noemen, en die de anderen nu (vanuit die zekerheid) om hun geloofspapieren durven vragen. Hij moet bereid zijn een zeker pseudo-Christelijk engagement, een al te zelfverzekerde (materieelinhoudelijke) getuigenis van zichzelf als Christen te verzaken. Let wel: hij is niet bang om, als dat moet, als martelaar te sterven voor zijn geloof. Wel is hij bang wat zijn dood zou betekenen door wat hij daarover zegt: door zichzelf apodictisch als Christen (voor God) te willen opofferen. Nog eens: dat is niet Christelijk. Een Christen moet bereid zijn zich teweer te stellen tegen de verleidingen van zo een lafhartig engagement. Hij moet juist terughoudend zijn zich zo als Christen te bekennen, in weerwil van de 'grote urgentie' waarmee 'de huidige sociale problemen' zich aan ons opdringen, en die nu - zo berichten de media althans - om een waar en eenduidig Christelijk reveil vragen; een reveil dat 'nu absoluut geen uitstel meer duldt'. In een harde en frontale ontkenning van om het even welk criterium of sjibbolet (om te bepalen of men al dan niet tot het Christendom behoort), moet een Christen volhouden dat het bij het Christendom juist gaat om de innerlijkheid van de enkeling tegenover de Afwezige God, en niet slechts om een uiterlijk bewijs of getuigenis (Gr. martyreo). Alleen deze Afwezige Rechter kan oordelen of ik een Christen ben. En omdat het ideale Christendom eerst en vooral deze immateriële of spirituele innerlijkheid van mij vraagt, moet ik dit oordeel voor mijzelf (en voor anderen) in suspens houden. En ik mag mij niet tooien met een martelaarschap in een gemakkelijke, uiterlijke zin; zoals ik doe, wanneer ik toegeef aan de druk van de buitenwereld, mij in 'positieve' zin als Christen op te werpen en mij daarvoor te laten doodslaan.

Zoals gezegd: deze neutraal-polemische stellingname tegen de verdediging vergt een eigen, meer radicale opofferingsgezindheid en dapperheid; een dapperheid in geestelijke zin, die als zodanig geheel en al verschilt van die van de Grieken. Het martelaarschap van een Christen betekent de onzekerheid van het geloof vol te houden, in weerwil van al diegenen die ons op de proef willen stellen. Met kracht van argumenten eisen zij helderheid, en eerst en vooral omwille van hun eigen zielenheil. Want de verdedigers van het Christendom zijn voor zichzelf niet in staat de suspens van het geloof uit te houden, en het ideale Christendom en het voorbeeld van de geloofsridder zijn voor hen een grote ergernis. Waarom is deze suspens nu zo belangrijk voor de wijze waarop Kierkegaard zich als Christen wil positioneren? Welnu, in zijn tijd, alsook in de tijd waarin wij leven is er niemand meer die nog halt houdt bij het geloof. Allemaal willen zij verder; aldus reeds Johannes de Silentio in het korte voorwoord bij Vrees en Beven (1843). De verdedigers van het Christendom (toen 
en nu) voelen een onweerstaanbare drang naar het 'materiële' en 'positieve'. Het is een drang die zondig is, en louter psychologisch verklaarbaar uit hun angst voor het 'negatieve', die de prijs van het geloof voor hen te hoog maakt. Deze aandrang tot het positieve vindt men ook bij sommige verliefden die zich met de verliefdheid alleen niet tevreden kunnen stellen en een diepe zucht naar uiterlijke zekerheid voelen. Zo ook sommige filo-sofen ${ }^{33}$, die hun liefde voor de wijsheid veel liever voor het bezit daarvan willen inruilen. Socrates daarentegen, was een verliefde die de zekerheid verzaakte, en vasthoudend 'onder sterren leefde'. Wellicht is er nooit een groter mensenkenner geweest dan Socrates, die bovendien ook zichzelf goed kende. Het hoogtepunt, het summa summarum van zijn kennis is echter, dat hij zelfs niet met zekerheid wist te zeggen of hij überhaupt een mens was ${ }^{34}$; tenminste zolang hij niet wist wat het werkelijk betekende een mens te zijn (d.i. als mens te existeren). En zolang hij over zichzelf nog zo onwetend was, heeft het Socrates belachelijk geleken om aan andere dingen te denken. Zo echter, is het niet gegaan en gaat het niet met talloos veel zogenaamde Christenen. De meesten willen van geen uitstel weten, en zonder eerst in zichzelf te zoeken naar wat het werkelijk inhoud Christen te zijn (een taak voor het leven), zónder geloof in vrees en beven, leven ze in de waan van zichzelf al lang te weten dat zij Christen zijn. En in hun waanwijsheid matigen zij zich aan hun laffe Christendom te verdedigen en aan anderen op te dringen (Pap. X 5B 105-114). Daartegen komt Kierkegaard in het geweer; dat is wat hij voorheeft met zijn 'bewapende neutraliteit'. Hij houdt stand in het geloof, dat hem voor zichzelf steeds opnieuw weer een vreemde maakt. ${ }^{35}$ Hij hoopt deemoedig (tegenover God!) dat hij Christen mag zijn. En hij hoopt en gelooft dat God hem in genade als Christen zal willen aannemen. Hij gelooft het 'slechts', want het geloof is de hoogste hartstocht: "menigeen in iedere generatie zal zover nooit komen, maar niemand komt ooit verder".36

33 Cf. Hegel, Phänomenologie des Geistes, Hamburg, 1988, p.6: "Daran mitzuarbeiten, daß die Philosophie der Form der Wissenschaft näher komme, - dem Ziele, ihren Namen der Liebe zum Wissen ablegen zu können und wirkliches Wissen zu sein, - ist es, was ich mir vorgesetzt."

34 Zie Plato, Phaedrus 229e-230a.

35 In een wereld vol 'Christenen' houdt Kierkegaard staande dat hijzelf, die de verhevenheid ervan zó ernstig neemt, geen Christen is. Want door de liefde voor God, wordt men een vraagteken voor zichzelf, en juist die radicale onzekerheid over de eigen identiteit is constitutief voor het waarlijk Christen-zijn; al staat dit 'uitstel' een vereniging in de zin van de Christenheid wél in de weg. Vgl. Augustinus: "Wat bemin ik, wanneer ik u bemin?" Bekentenissen, Boek X: 6, 8. En: "Ik ben mijzelf tot een raadsel geworden (mihi questio factus sum)". Ibidem, X: 33.50. Cf. Paulus, Rom. 7:15.

36 Cf. de epiloog bij Vrees en Beven. 


\section{$\S 8$ Conclusie}

We hebben gezien wat een enorme vergissing het is het Christendom te willen beschouwen en begrijpen; ook hebben we gezien welke gedaanteverandering het Christendom doormaakt als de waarheid daarvan zo voortdurend gedoceerd wordt.

Iedere boom herkent men aan zijn vruchten (Luc. 6:44) ${ }^{37}$; dat geldt voor de vrucht van de liefde (de daad van liefde), maar hetzelfde geldt voor de wrange vruchten van de Boom der Kennis. De verdediging beoogt met een krachtig Christelijke Reveil een oplossing te bieden voor de huidige morele crisis. Met die crisis bedoelt men de versplintering van de traditionele gemeenschappelijke religieuze en culturele horizon die voor de zingeving en de ethiek van het individu een belangrijke, concreet-algemene voedingsbodem zou vormen. Echter, de crisis zoals Kierkegaard die ziet is een andere. Het probleem voor hem is niet, het meer en meer ontbreken van een globale, gemeenschappelijkgedeelde wereldbeschouwing of ideologie. Niet alleen is dat weinig praktisch gezien de voor de moderniteit kenmerkende, Babylonische 'onoverzichtelijkheid' die inderdaad wijst op een radicale en onomkeerbare divergentie van steeds meer verschillende, persoonlijke perspectieven en keuzes aangaande kwesties van zin en waarde (ook in de tijd van Kierkegaard werd deze ontwikkeling al zichtbaar). Maar buitendien wordt het Christendom, door het voor dit slechts relatieve doel in te zetten, op slinkse wijze verraden. Het probleem voor Kierkegaard is, dat de vrijheid die men doorheen de Reformatie en de Verlichting verkregen heeft niet op eigenlijke wijze wordt opgevat. Dát is de eigenlijke crisis van deze tijd: dat het ernstige engagement met de vrijheid van de existentie wordt afgewenteld en uit de weg gegaan, hetzij in een vrijblijvend esthetische bestaanswijze (en die omvat nadrukkelijk ook die vorm van vertwijfeling waarin de wetenschap en het denken verkeren), hetzij in een anonieme, slechts algemene ethische levensbeschouwing.

Ik kom nu tot een besluit van deze (schetsmatige, niet uitputtende) reconstructie van Kierkegaards indrukwekkende, opbouwende apologie van het Christendom van het Nieuwe Testament; een Christendom dat zich wezenlijk polemisch verhoudt tegenover het algemene. Überhaupt is het voor hem weinig Christelijk om zich zorgen te maken over de toekomst van het Christendom als fundament van de cultuurgemeenschap. Met de idee van de gemeente, het sociale (dit grote Christelijke gezelschapsspel), zijn we in ieder geval oneindig ver verwijderd van de

37 Cf. Kierkegaard, Wat de liefde doet, pp. 13-26 (SKS 9, 13-25). 
volheid van de tijd. De verlossing wordt niet bevorderd door een pleidooi voor 'meer religie', maar juist door een gerede scepsis daarover, en door de bevordering van een 'religie zonder religie'. Men doet er beter aan: "[...] iedere verdediging van het Christendom achterwege te laten dan er bewust of onbewust van alles bij in te willen lijven - ook het niet-Christelijke." 38 Inderdaad heeft het Christendom de gemeenschap, de broederschap en het patriottisme van de troon gestoten. En het is de verwarring hierover, die door de verdediging alsmaar verder wordt aangewakkerd en versterkt, die het de enkeling in de weg staat een duidelijke keuze te maken. Het is het één of het ander. Men bewijst het Christendom geen dienst met een dialectisch 'zowel - alsook'. Echte gemeenschappelijkheid (óók: het samenleven met andere culturen) is gefundeerd in de relatie van de enkeling tot God. Dat geldt ook voor de natuurlijke liefde, de vriendschap en het huwelijk ${ }^{39}$, die allen evenzeer door de Godsverhouding (de naastenliefde) getransformeerd moeten worden. Pas wanneer het afzonderlijke individu een dergelijke verhouding heeft verworven kan men zich in waarheid verenigen, hoewel de eigenlijke congregatie die een Christen zoekt pas in de eeuwigheid te vinden is. ${ }^{40}$ Dát moet dus voor een Christen de primaire zorg zijn. Een sociale cohesie die niet uit die eigenlijke religiositeit groeit, maar slechts omwille van zichzelf gezocht wordt, is net zo heilloos, lelijk en verderfelijk als 'kinderen die gaan trouwen'41. "Niemand kan twee heren dienen" (Matt. 6:24). De navolging van Christus als Voorbeeld; dáár valt de beslissing of men het Christendom wil aannemen of niet. Als men dit punt zou willen benadrukken in de verkondiging daarvan, blijven er misschien nóg minder Christenen over, maar wat dan resteert leeft tenminste.

38 Idem, p. 56 (SKS 9, 52).

39 Ook op dit punt staat Kierkegaard diametraal tegenover het gemeenschapsidealisme van Hegel. In zijn Rechtsfilosofie zegt laatstgenoemde dat het religieuze karakter van huwelijk en familie, de piëteit of vroomheid van beide, juist gelegen is in de zedelijke samensmelting, waardoor de beide liefdespartners werkelijk één persoon worden (en de afzonderlijke leden van die gemeenschap op zichzelf bezien nog slechts Accidenzen vormen). Cf. Grundlinien $\S \S 162-163$ Anm.. Maar vanuit het perspectief van de ware liefde staat de beoogde eenheid de zuivere en onvoorwaardelijke liefde voor de ander juist in de weg, en de vereiste zelfverloochening vraagt van ons dat wij die eenheid opofferen. De ware, vrije en onafhankelijke liefde voor de ander brengt mij ertoe die ander vrij te laten en op zichzelf te stellen (eventueel zelfs 'af te stoten') om die aldus op het spoor van de liefde voor God te brengen. Vgl. Luk. 14:26: "Indien iemand tot mij komt en niet haat zijn vader en moeder, zijn vrouw, zijn kinderen, zijn broeders en zusters, ja zelfs zijn eigen leven, die kan mijn discipel niet zijn."

40 Wanneer de Christenheid het ideaal van de gemeente zó nadrukkelijk op dit leven van toepassing verklaart, dan getuigt dat van een ongeduldige anticipatie op het eeuwige. Het Christendom is de strijd van het enkele individu vóór de liefde van God en tégen de wereld; d.i. een wereld waarin wij slechts in het lijden met God gelijktijdig zijn. Cf. Kierkegaard, Oefening in Christendom, SKS 12, 216-218.

41 S. Kierkegaard, 'Een literaire recensie' (1846) in Denken en zijn, Meppel/Amsterdam, Boom, 1982, p. 160. 
Wordt er daarentegen op dit punt afgedongen, wordt er van het Christendom een 'horizontale ethologie' gemaakt, en men gebruikt zijn verstand om zichzelf en anderen te verontschuldigen, dan wordt het inderdaad voor steeds meer mensen bereikbaar en aannemelijk. Aldus op directe wijze gedoceerd, breidt het Christendom zich dan eventueel uit tot het uiteindelijk geheel met de gehele wereld komt samen te vallen. Het Christendom heeft dan inderdaad volkomen gezegevierd (want iedereen is Christen), maar het is dan ook wel geheel en al afgeschaft! Het religieuze verhoudt zich absoluut tot het absolute en relatief ten opzichte van het relatieve. Voor zover het zichzelf nog identificeert met het slechts relatieve - zoals ook de apologie van het Christendom is - moet het zelf zich opofferen en ongelijkvormig worden. Want alles van waarde is weerloos. Zo heeft ook Christus zich opgeofferd door een gelatenheid ten opzichte van het geweld van hen die hem naar het leven stonden. Deze reserve ten opzichte van de wereld, deze resignatie, dít martelaarschap vormt het eigenlijke ethos van hen die Christus als voorbeeld nemen. De verdediging daarentegen is voor verliezers, die nooit werkelijk geloofd hebben. De verdediging levert een achterhoedegevecht dat bij voorbaat verloren is, want het echt Christelijke is de aanval en de overwinning (SKS 11, 201). Christus zélf waarschuwt tegen de bezorgdheid om dingen die te zeer 'van deze wereld' zijn. Zoek de stilte, want die is het medium van de geest. "Zoek het Koninkrijk Gods"; zoek eerst zijn gerechtigheid, en de rest zal je gegeven worden (Matt. 13:44). Eerst het Rijk Gods; en dus niet pas op het laatst; niet eerst nog die zorg om al die andere, aardse zaken. Kijk naar de vogels in de lucht; zie de lelies in het veld! Zij bekommeren zich niet, en tóch: "zelfs Salomo ging in al zijn luister niet gekleed als een van hen" (Matt. 6:29). ${ }^{42}$

Dr. Timo Slootweg (1962) is als universitair docent rechtsfilosofie en ethiek verbonden aan de Universiteit Leiden. Hij promoveerde op het proefschrift: Geschiedenis en ethiek. Historisch besef in de traditie van Hegel, Heidegger en Derrida (Damon, Leende, 2000). Recente publicaties in boekvorm: Kant-lijnen. Filosofie en de idee van de universiteit (red. met Donald Loose) (Damon, Budel, 2002); Bij tijd en wijle. Essays over rust als ethos (red.) (Aspekt, Soesterberg, 2004); In de schaduw van de Boom der Kennis. Ethiek en de zondeval (red.) (Damon, Budel, 2005) en Hegel actueel. Hedendaagse perspectieven op Hegels wijsgerige relevantie (red. met Jeroen Buve) (Deventer Universitaire Pers, Deventer, 2008).

Adres: Faculteit der Rechtsgeleerdheid - Universiteit Leiden, Departement Metajuridica, Afdeling Rechtsfilosofie, Steenschuur 25, 2300 RA Leiden.

Email: T.J.M.Slootweg@law.leidenuniv.nl

42 Kierkegaard, 'De lelie op het veld en de vogel in de lucht. Twee vrome redevoeringen', 1849, SKS 11, 7-48. 